\title{
EDITORIAL
}

\section{Artículo científico: pautas para redactar los resultados}

En esta sección están los elementos que permiten cumplir con el fin primordial de toda publicación científica: comunicar los resultados de la investigación. Si sólo un número reducido de datos será divulgado, inserte la información en un texto (no use tablas o figuras). Elija entre una tabla o una figura para expresar un resultado, nunca las dos cosas a la misma vez; aunque no todos los resultados precisan ser divulgados en estas formas. A veces redactar un resultado en un texto simple y concreto, ayuda a la no confusión ¡Evite la redundancia!

A continuación, algunas consideraciones importantes a tener en cuenta al redactar los resultados:

$\checkmark$ Seleccionar resultados representativos.

$\checkmark$ Declarar cualquier ajuste o uso de software de procesamiento de imágenes utilizado.

$\checkmark$ Aprovechar bien el uso figuras, juntar figuras que tengan afinidad podría ser una buena estrategia.

$\checkmark$ Evitar manipular las imágenes para cambiar o mejorar los resultados; ajustar el brillo o el contraste de una imagen sólo es aceptable si se aplica de forma similar en todas las imágenes, incluidos los controles. Crear imágenes autoexplicativas no significa manipulación, es incluso un elemento muy deseado actualmente en las publicaciones.

Sugerencia final:

Sea ordenado al momento de recopilar, organizar o graficar sus resultados y guarde copias de los archivos, metadatos y otros que fueron utilizados para crear sus figuras o no, ya que éstos pueden ser solicitados por la revista durante el proceso de revisión.

Ph D. Raúl Siche 